\title{
Fabrication and Characterization of Highly Textured Thin Films of Undoped and Ag-Doped $\mathrm{ZnO}$
}

\author{
A. Herzi $^{a, *}$, M. Sebais ${ }^{a}$, B. Boudine ${ }^{a}$, O. Halimi ${ }^{a}$, B. Rahal ${ }^{b}$ And L. Guerbous ${ }^{b}$ \\ ${ }^{a}$ Crystallography Laboratory, Physics Department, Faculty of Exact Sciences, \\ Mentouri Brothers-Constantine 1 University, Route Ain El Bey, Constantine 25000, Algeria \\ ${ }^{b}$ Nuclear Technical Division, Nuclear Research Center of Algiers, 2 Bd., Frantz Fanon, BP 399, Algiers 16000, Algeria
}

(Received December 17, 2018; in final form February 9, 2019)

\begin{abstract}
Undoped and Ag-doped $\mathrm{ZnO}$ thin films with different silver concentrations (0,1,3, and 7 wt $\%$ ) were synthesized by sol-gel method and deposited onto glass substrate by dip-coating technique. Zinc acetate dehydrate and silver nitrate were used as starting materials. 2-Methoxyethanol and ethanolamine were used as solvent and stabilizer. Characterization by X-ray diffraction has revealed that the undoped and Ag-doped $\mathrm{ZnO}$ are polycrystalline, and have the wurtzite hexagonal structure with a preferred orientation along $c$-axis. The nanometric size $(27-34 \mathrm{~nm})$ of $\mathrm{ZnO}$ crystallites varies with the concentration of Ag. The surface morphology analysis, by atomic force microscopy and scanning electron microscopy, depicts a homogeneous dispersion of $\mathrm{ZnO}$ crystallites in the form of randomly spread wrinkles-like formation. The Raman spectroscopy confirms the Ag incorporation in the $\mathrm{ZnO}$ lattice. All films exhibit a transmittance greater than $75 \%$ in the visible region, and a sharp absorption band at $325 \mathrm{~nm}$ corresponding to the fundamental absorption edge. The room-temperature photoluminescence spectra of the prepared thin films display a strong ultraviolet band at $380 \mathrm{~nm}$ originated from excitons recombination, and four bands in the visible region at $430 \mathrm{~nm}$ (violet), $460 \mathrm{~nm}, 480 \mathrm{~nm}$ (blue) and $530 \mathrm{~nm}$ (green) from created defect levels in the band gap. These synthesized materials may be potential candidates in the manufacture of devices using short wavelengths.
\end{abstract}

DOI: 10.12693/APhysPolA.135.526

PACS/topics: ZnO, Ag, thin films, sol-gel, X-ray diffraction, photoluminescence

\section{Introduction}

Recently, the synthesis of nanostructured thin films based on zinc oxide has been intensively investigated. These nanostructures have been applied in lot of physics devices like light-emitting diodes [1], window materials in solar cells $[2,3]$, gas sensors $[4,5]$, and photocatalysts [6-8]. Moreover, the $\mathrm{ZnO}$ has a direct wide band gap energy $(\approx 3.37 \mathrm{eV}$ at room temperature $)$ and a high excitonic binding energy $(60 \mathrm{meV})$, which make it a suitable material for optoelectronics [9].

Various techniques have been used to prepare the $\mathrm{ZnO}$ thin films. These techniques include the chemical vapor deposition [10], electrochemical deposition [11], spray pyrolysis [12-14], sol-gel method [15-17]. Among the techniques mentioned above, the sol-gel process has attracted a great attention due to its excellent homogeneity, low cost, easy control of doping, and chemical composition, good reproducibility, lower crystallization temperature and large-area coating capability with high adhesion on different types of substrates [18]. It has been reported that the doping of $\mathrm{ZnO}$ with various metal elements such as indium (In), aluminum ( $\mathrm{Al}$ ), and gallium (Ga) improve its structural, electrical, and optical properties $[19,20]$. In particular, among these $\mathrm{ZnO}$-based

*corresponding author; e-mail: herzikarim@yahoo.fr materials, Ag-doped $\mathrm{ZnO}$ thin films have been intensively studied during the last decade due to their low cost, nontoxicity, low electrical resistivity, and high optical transmittance [21, 22].

In this work, the effects of silver doping (concentration of Ag: 0, 1, 3, and $7 \mathrm{wt} \%$ ) on the structural and optical properties of $\mathrm{ZnO}$ thin films were examined. It was proposed earlier that the substitution sites are more energetically favorable than the interstitial sites for the synthesis and growth of $\mathrm{ZnO}$ crystals [6]. So $\mathrm{ZnO}$ and $\mathrm{Ag}-\mathrm{ZnO}$ thin films were deposited onto glass substrates by dip-coating technique. Different techniques were used to investigate the evolution of the structural and optical properties of Ag-doped $\mathrm{ZnO}$ thin films with increase of Ag concentration.

\section{Experimental}

The undoped and Ag-doped $\mathrm{ZnO}$ thin films were prepared by sol-gel process and deposited on glass substrates by dip-coating technique. In a typical synthesis, the zinc acetate dehydrate $\left[\mathrm{Zn}\left(\mathrm{CH}_{3} \mathrm{CO}_{2}\right)_{2} \cdot 2 \mathrm{H}_{2} \mathrm{O}\right.$, $\mathrm{ZnAc}]$ as $\mathrm{Zn}$ source, and the silver nitrate $\left[\mathrm{AgNO}_{3}\right]$ as $\mathrm{Ag}$ source, are used as starting materials. The molar ratios of $[\mathrm{Ag}] /[\mathrm{Zn}]$ were $0,1,3$, and $7 \mathrm{wt} \%$. The mixture $(0.75 \mathrm{~g})$ was dissolved in 2-methoxyethanol $(20 \mathrm{ml})$ under vigorous magnetic stirring. The resulting solution was followed by drop wise addition of ethanolamine $(0.4 \mathrm{ml})$. The obtained solution was stirred for $120 \mathrm{~min}$ 
at $60^{\circ} \mathrm{C}$. After this heat treatment the final solution becomes transparent and homogeneous. To obtain $\mathrm{ZnO}$ and $\mathrm{Ag}-\mathrm{ZnO}$ thin films, the cleaned glass substrates were immersed and withdrawn from the solution at the rate of $0.8 \mathrm{~cm} / \mathrm{min}$. Before the deposition of the films, the glass substrates were rinsed in an ultrasonic bath with distilled water, ethanol, and acetone then dried at room temperature. Finally, the thin films samples thus obtained were dried at $350{ }^{\circ} \mathrm{C}$ for $10 \mathrm{~min}$, and annealed at $500^{\circ} \mathrm{C}$ for $1 \mathrm{~h}$. The crystalline structure was analysed with X-ray diffraction (XRD), using a PANalytical X'Pert Pro Philips diffractometer $\left(\lambda_{\mathrm{Cu}}=1.54059 \AA\right)$. The Raman spectroscopy was carried out by a Bruker-Senterra spectrophotometer using an excitation wavelength of $532 \mathrm{~nm}$. The morphology and the topography of films were observed by scanning electron (SEM, Philips microscope) and atomic force (AFM, A100 model of APE Research) microscopies. The optical UVvisible absorption was measured using a UV-vis spectrophotometer (JASCO V-750), and the photoluminescence spectra were recorded using an excitation wavelength of $250 \mathrm{~nm}$ from a Perkin-Elmer LS 50B luminescence spectrophotometer.

\section{Results and discussion}

\subsection{X-ray diffraction analysis}

The XRD patterns of undoped and Ag-doped $\mathrm{ZnO}$ thin films, with different $\mathrm{Ag}$ concentrations (1, 3, and $7 \mathrm{wt} \%)$, deposited onto glass substrates, are presented in Fig. 1.

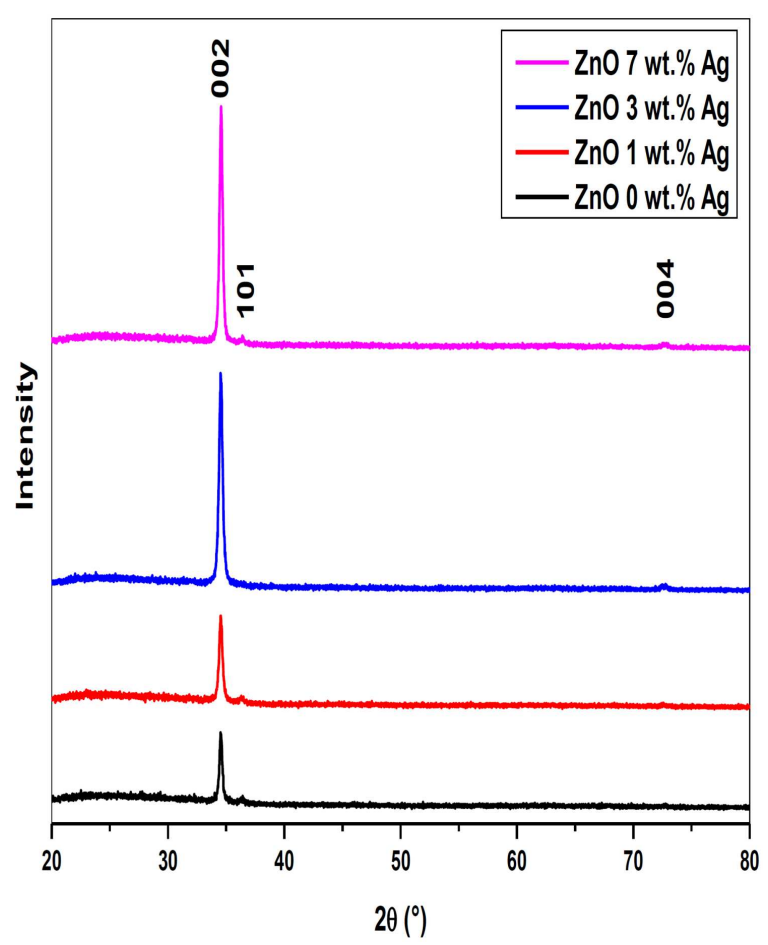

Fig. 1. X-ray diffraction diffractograms of undoped and $\mathrm{Ag}$-doped $\mathrm{ZnO}$ thin films with different $\mathrm{Ag}$ concentrations (1, 3, and $7 \mathrm{wt} \%)$.

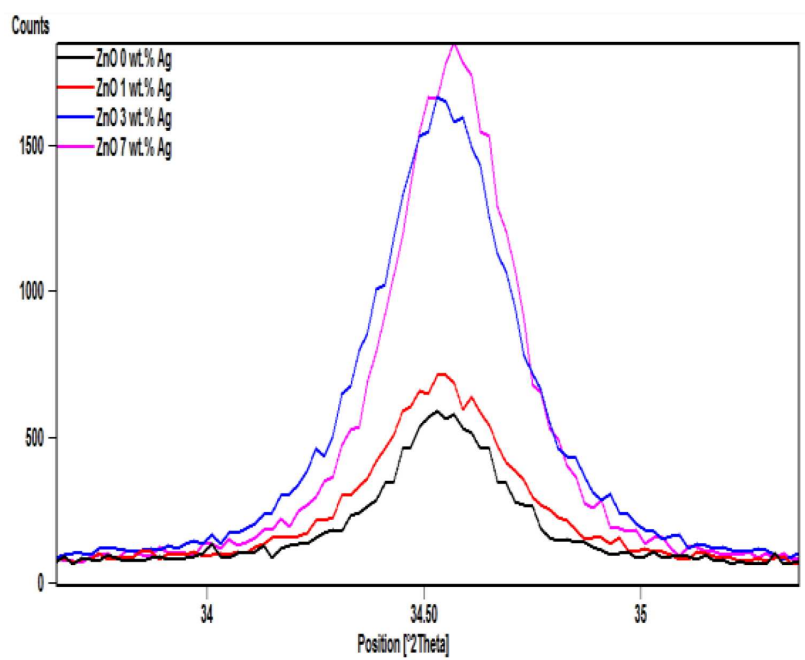

Fig. 2. Evolution of the (002) peak intensity of undoped and $\mathrm{Ag}$-doped $\mathrm{ZnO}$ thin films with different $\mathrm{Ag}$ concentrations $(1,3$, and $7 \mathrm{wt} \%)$.

The spectra show that all films are polycrystalline, and are highly textured since they exhibit a very intense peak at $2 \theta=34.52^{\circ}$ and a very weak peak at $2 \theta=72.58^{\circ}$, which correspond, respectively, to the plane (002) and its harmonic (004) of hexagonal (wurtzite) structure of $\mathrm{ZnO}$, according to the JCPDS card file No. 00-36-1451 [23]. This result indicates a high preferential $c$-axis orientation of $\mathrm{ZnO}$ crystallites [24-27]. The third peak observed at $2 \theta=36.35^{\circ}$ is also very weak and it is from the plane (101). As for earlier synthesis [28], there are no other detected peaks corresponding to secondary phases.

From Fig. 2, we can note that the intensity of (002) peak increases with increase of the Ag concentration, and so we can conclude that the crystallinity of the films is improved by the Ag doping.

The crystallite size of undoped and Ag-doped $\mathrm{ZnO}$ thin films were estimated using Scherrer's formula $[29,30]$ :

$$
D=\frac{0.9 \lambda}{\beta \cos \theta}
$$

where $D$ is the crystallite size, $\lambda$ is the wavelength, $\theta$ is the Bragg angle, and $\beta$ is the full width at half-maximum (FWHM) of the peak.

On the other hand, the $\mathrm{ZnO}$ lattice strain $\sigma$ [GPa] were calculated using the following relations [31]:

$$
\begin{aligned}
& c_{33}^{\text {film }}=\frac{0.99 c_{33}^{\text {cristal }}}{\left(1-e_{z z}\right)^{4}}, \\
& \sigma=\left[2 c_{13}-\frac{\left(c_{11}+c_{12}\right) c_{33}^{\text {film }}}{c_{13}}\right] e_{z z}, \\
& e_{z z}=\frac{c_{0}-c}{c_{0}},
\end{aligned}
$$

where $C_{i j}$ are the elastic constants of $\mathrm{ZnO}$ admit the following values: $c_{11}=209.7 \mathrm{GPa}, c_{12}=121.1 \mathrm{GPa}$, $c_{13}=105.1 \mathrm{GPa}, c_{33}=210.9 \mathrm{GPa}$ and $c_{0}=5.20661 \AA$. $C$ is the calculated $\mathrm{ZnO}$ lattice parameter along [002] axis. 
TABLE I

The crystallite size values, the strains and parameters of the lattice of undoped and Ag-doped $\mathrm{ZnO}$ thin films (data from (002) peak).

\begin{tabular}{c|c|c|c|c|c|c|c}
\hline \hline $\begin{array}{c}\mathrm{Ag} \\
{[\mathrm{wt} \%]}\end{array}$ & $\begin{array}{c}2 \theta \\
{\left[{ }^{\circ}\right]}\end{array}$ & $\begin{array}{c}D \\
{[\mathrm{~nm}]}\end{array}$ & $\begin{array}{c}a \\
{[\AA]}\end{array}$ & $\begin{array}{c}c \\
{[\AA]}\end{array}$ & $\begin{array}{c}e_{Z Z} \\
\times 10^{-4}\end{array}$ & $c_{33}^{\mathrm{film}}$ & $\begin{array}{l}\sigma^{*}(-) \\
{[\mathrm{GPa}]}\end{array}$ \\
\hline 0 & 34.52 & 34 & 3.244 & 5.192 & 28 & 211.146 & 1.272 \\
1 & 34.51 & 29 & 3.248 & 5.206 & 12 & 209.796 & 0.540 \\
3 & 34.52 & 27 & 3.241 & 5.206 & 12 & 209.796 & 0.540 \\
7 & 34.54 & 33 & 3.235 & 5.201 & 11 & 209.712 & 0.495
\end{tabular}

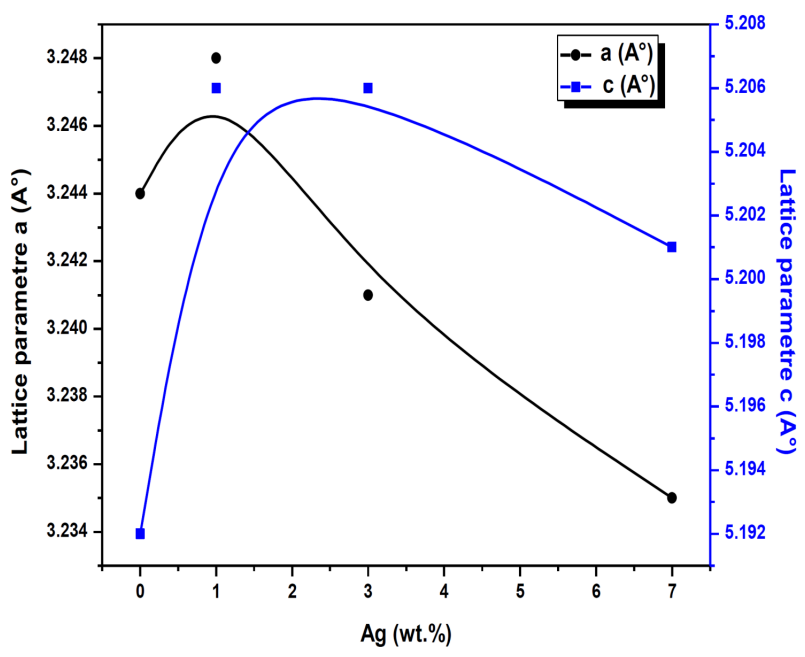

Fig. 3. Evolution of the cell parameters $a[\AA]$ and $c[\AA]$ of $\mathrm{ZnO}$ thin films with different $\mathrm{Ag}$ concentrations (0, $1,3$, and 7 wt $\%)$.

The cell parameters are calculated using the relations

$$
\begin{aligned}
& d_{h k l}=\frac{1}{\sqrt{\frac{4}{3}\left(\frac{h^{2}+k^{2}+h k}{a^{2}}\right)+\frac{l^{2}}{c^{2}}}} \Rightarrow c=2 d_{002}, \\
& a=\sqrt{\frac{4}{3}\left(\frac{h^{2}+k^{2}+h k}{\frac{1}{d_{h k l}^{2}}-\frac{l^{2}}{c^{2}}}\right)} .
\end{aligned}
$$

The results of the average size of $\mathrm{ZnO}$ crystallites, the lattice strain and the cell parameters are reported in Table I.

The evolution of cell parameters, according to the percentage of $\operatorname{Ag}(0,1,3$, and $7 \mathrm{wt} \%)$, are shown in Fig. 3. We note that the parameters $a$ and $c$ increase for the low percentages and decrease for the high percentages of $\mathrm{Ag}$. This result is confirmed by the shift of the peak (002) towards the smaller and larger angles. This change in the cell parameters has, necessarily, repercussions on the optical properties of the prepared $\mathrm{ZnO}$ thin films.

\subsection{Raman analysis}

Figure 4 displays the Raman spectra of undoped and Ag-doped $\mathrm{ZnO}$ thin films with different $\mathrm{Ag}$ concentrations $(0,1,3$, and $7 \mathrm{wt} \%)$. The spectra exhibit compressive stress due to the substitution of $\mathrm{Zn}^{2+}$ (radius $0.74 \AA$ )

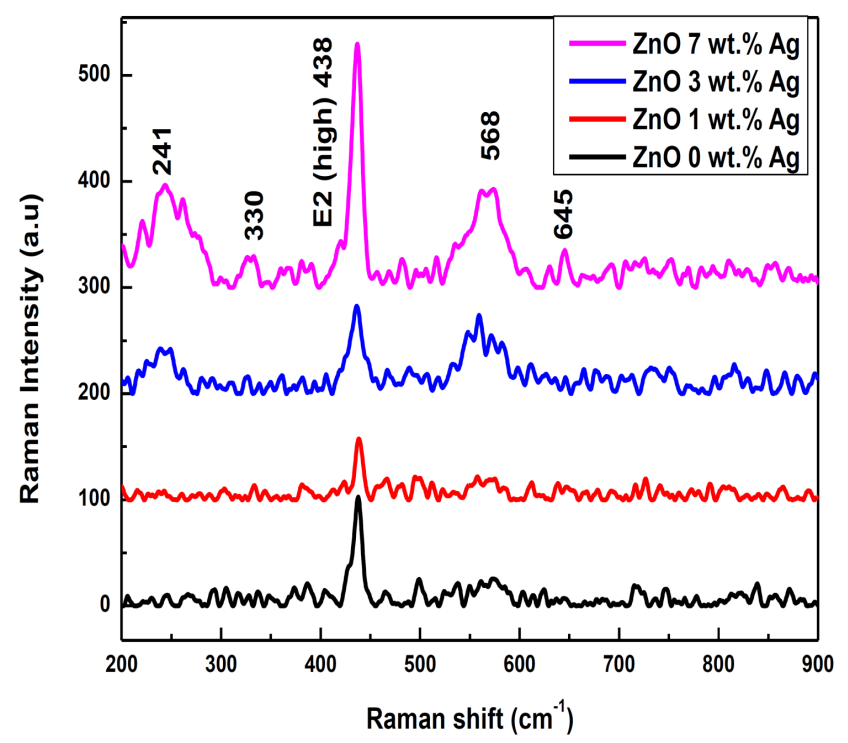

Fig. 4. Raman spectra of undoped and Ag-doped $\mathrm{ZnO}$ with different $\mathrm{Ag}$ concentrations $(1,3$, and $7 \mathrm{wt} \%)$.

by $\mathrm{Ag}^{2+}$ (radius $0.89 \AA$ ) in $\mathrm{ZnO}$ lattice. The intense peak, situated at $438 \mathrm{~cm}^{-1}$ was assigned to the vibrational modes E2 (high) [32, 33], its intensity increases when $\mathrm{Ag}$ concentration increases, which indicates that the crystal quality of $\mathrm{ZnO}$ nanoparticles was improved, and $\mathrm{ZnO}$ crystallites have a high preferential $c$-axis orientation. In addition to the E2 (high) phonon mode, the intensity of the A1 (LO) mode, at $568 \mathrm{~cm}^{-1}$, increases with increasing percentage of Ag. The A1(LO) was attributed to defects such as oxygen vacancies, interstitial $\mathrm{Zn}$ in $\mathrm{ZnO}[34,35]$ or/and probably to the mode frequencies of glass substrate [33].

While the peaks at 330 and $645 \mathrm{~cm}^{-1}$ are from multiphonon modes [36], the smaller peak originating at $330 \mathrm{~cm}^{-1}$ is attributed to a $E_{2 H^{-}} E_{2 L}$ (multi-phonon) [7] and for $645 \mathrm{~cm}^{-1} c$ peak can also be attributed to the aggregates of $\mathrm{Ag}$ element doping with the start of its supersaturation [37]. Therefore, we can say that these two peaks of $\mathrm{ZnO}$ modes confirmed the results of XRD analysis. Moreover, the increase of Ag doping concentration up to $7 \mathrm{wt} \%$ leads to ameliorate the crystallization of $\mathrm{ZnO}$ phase. This is clearly observed by the increase of the intensity and the width of (002) intense peak in our diffractograms (Figs. 1 and 2). We observed also a supplementary peak at about $241 \mathrm{~cm}^{-1}$ in the Raman spectra of Ag-doped $\mathrm{ZnO}$ with 3 and 7 wt\% of Ag doping. Mosquera et al. have attributed similar peak to the local vibrational modes (LVMs). Indeed, the incorporation of $\mathrm{Ag}$ in the host lattice can introduce additional modes (LVMs) in the Raman spectra [32, 38].

\subsection{Surface morphology analysis}

The morphology of undoped and Ag-doped $\mathrm{ZnO}$ thin films was analysed by SEM. From Fig. 5, one can see that the surfaces of all films exhibit a wrinkles-like morphology. 

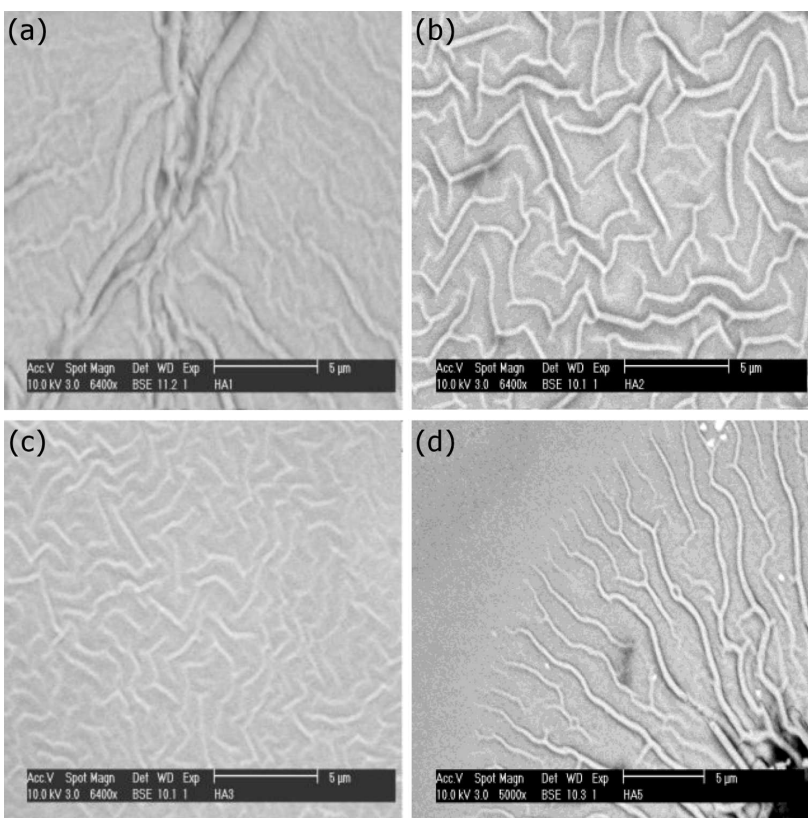

Fig. 5. SEM micrographs of $\mathrm{ZnO}$ thin films: (a) undoped $\mathrm{ZnO}$, (b) $\mathrm{ZnO}$ doped with $1 \mathrm{wt} \% \mathrm{Ag}$, (c) $\mathrm{ZnO}$ doped with $3 \mathrm{wt} \% \mathrm{Ag}$, and (d) $\mathrm{ZnO}$ doped with $7 \mathrm{wt} \% \mathrm{Ag}$.

The wrinkles-like formations are interconnected with each other, and do not have a particular orientation. Their length exceeds $10 \mu \mathrm{m}$. The wrinkles-like formations are thinner in the case of $\mathrm{ZnO}$ thin film doped with $3 \mathrm{wt} \% \mathrm{Ag}$. This morphology is similar to that observed by Rahal et al. [29] and Zegadi et al. [39], for $\mathrm{ZnO}$ thin films prepared by colloidal and sol-gel synthesis methods, respectively.

\subsection{Surface topography analysis}

Figure 6 shows the three-dimensional images of AFM of prepared $\mathrm{ZnO}$ thin films. We note that the distribution of $\mathrm{ZnO}$ particles on the surface of samples is uniform and the grain size is more important for the sample $\mathrm{ZnO}$ doped with $3 \mathrm{wt} \% \mathrm{Ag}$. The roughness increases with the concentration of $\mathrm{Ag}$ doping and the films exhibit a weak variation of roughness [37]. Therefore, the Ag doping affects the surface topography of films [40] and consequently can affect the optical properties.

TABLE II

Roughness by AFM of undoped and Ag-doped $\mathrm{ZnO}$ thin films with different $\mathrm{Ag}$ concentrations (1, 3, and $7 \mathrm{wt} \%$ ).

\begin{tabular}{c|c|c|c}
\hline \hline $\mathrm{Ag}[\mathrm{wt} \%]$ & $R_{a}[\mathrm{~nm}]$ & $R_{\mathrm{RMS}}[\mathrm{nm}]$ & $E_{g}[\mathrm{eV}]$ \\
\hline 0 & 0.24 & 0.30 & 3.30 \\
1 & 0.26 & 0.33 & 3.29 \\
3 & 0.36 & 0.54 & 3.27 \\
7 & 0.32 & 0.42 & 3.26
\end{tabular}
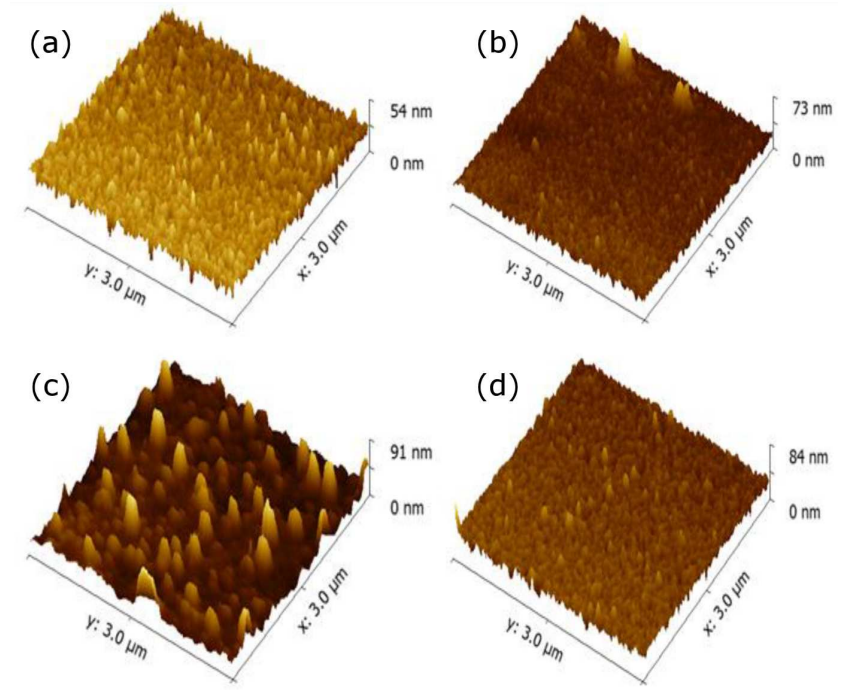

Fig. 6. AFM topography images of undoped and Agdoped $\mathrm{ZnO}$ thin films with different $\mathrm{Ag}$ concentrations $(1,3$, and 7 wt.\%).

The calculated average roughness $\left(R_{a}\right)$ and the rootmean square (RMS) roughness $\left(R_{\mathrm{RMS}}\right)$ are reported in Table II.

\subsection{Optical analysis}

Figure 7 displays the room temperature transmission spectra of undoped and $\mathrm{Ag}$-doped $\mathrm{ZnO}$ thin films in the wavelength range of 200-900 $\mathrm{nm}$. We can see that the optical transmittance in the visible range is greater than $75 \%$ and the samples display a cut-off wavelength at around $375 \mathrm{~nm}$.

The band gap energy $\left(E_{g}\right)$ of all films (undoped and Ag-doped $\mathrm{ZnO}$ ) has been determined using the Tauc method (Fig. 8). The values of $E_{g}$ are summarized in Table I. The values $(3.30-3.26 \mathrm{eV})$ are close to the band gap energy of the pure $\mathrm{ZnO}\left(E_{g}=3.37 \mathrm{eV}\right)[41,42]$.

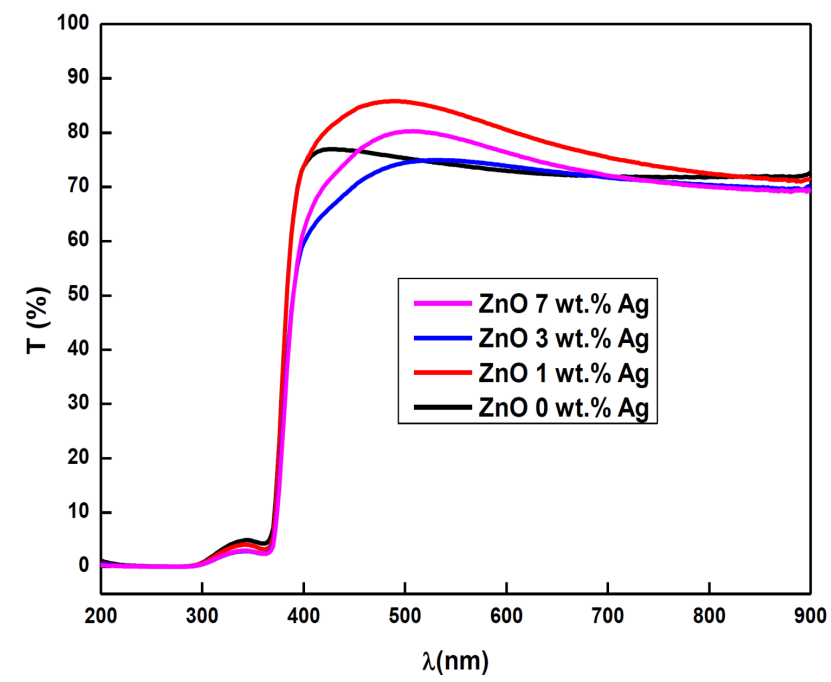

Fig. 7. Transmittance of $\mathrm{ZnO}$ and $\mathrm{Ag}$-doped $\mathrm{ZnO}$ thin films. 
The optical absorption edge exhibits a red-shift with the rise of $\mathrm{Ag}$ doping concentration. The observed band gap narrowing is due to the existence of $\mathrm{Ag}$ impurities in the $\mathrm{ZnO}$ cells, which is in agreement with literature $[24,25,43]$.

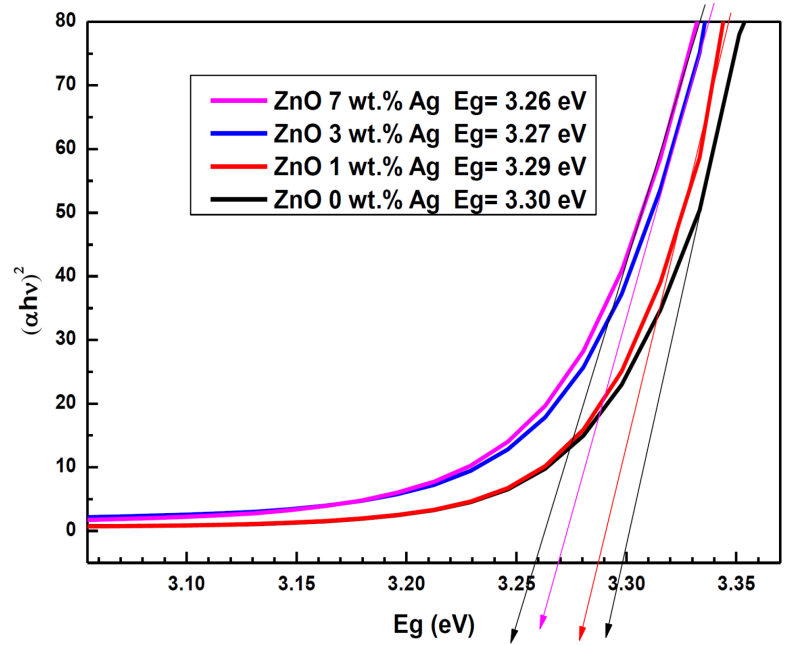

Fig. 8. Determination of the band gap energy of $\mathrm{ZnO}$ and $\mathrm{Ag}$-doped $\mathrm{ZnO}$ thin films.

\subsection{Photoluminescence analysis}

Figure 9 exhibits the room temperature photoluminescence spectra (excitation wavelength $325 \mathrm{~nm}$ ) of undoped and $\mathrm{Ag}$-doped $\mathrm{ZnO}$ thin films.

We remark that the PL signal is formed by five broadened bands. In order to determine the center of every luminescence band, the signal has been deconvoluted with the Gauss curve (Fig. 10).

Thus, the bands were located at $2.34 \mathrm{eV}(530 \mathrm{~nm})$, $2.58 \mathrm{eV}(480 \mathrm{~nm}), 2.70 \mathrm{eV}(460 \mathrm{~nm}), 2.88 \mathrm{eV}(430 \mathrm{~nm})$ and $3.26 \mathrm{eV}(380 \mathrm{~nm})$. The band at $3.26 \mathrm{eV}$ can be attributed to the exciton recombination corresponding to

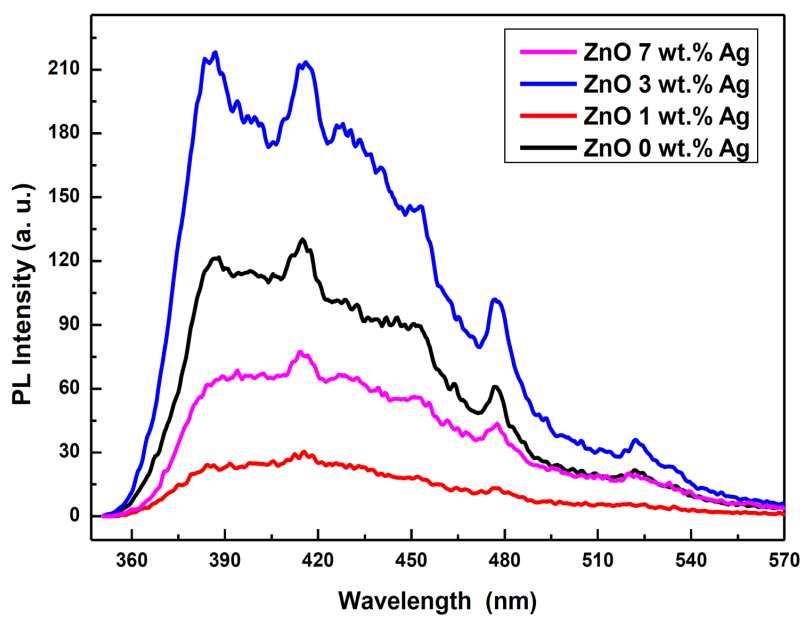

Fig. 9. Photoluminescence spectra of undoped $\mathrm{ZnO}$ and $\mathrm{Ag}$-doped $\mathrm{ZnO}$ thin films with different $\mathrm{Ag}$ concentrations $(1,3$, and $7 \mathrm{wt} \%)$.
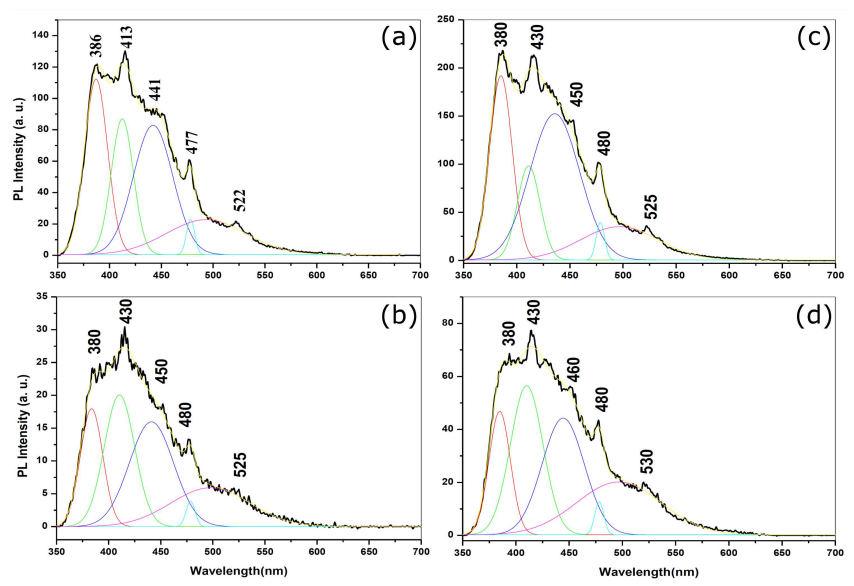

Fig. 10. Deconvolution of photoluminescence spectra of undoped and $\mathrm{Ag}$-doped $\mathrm{ZnO}$ thin films with different Ag concentrations (1,3, and 7 wt $\%)$.

the near-band edge transition (NBE) of $\mathrm{ZnO}$ [44]. The band observed at $2.88 \mathrm{eV}$ may be assigned to the transition energy of electron from conduction band to the zinc vacancy $V_{\mathrm{Zn}}$ [45]. The bands at $2.70 \mathrm{eV}$ and $2.58 \mathrm{eV}$ are originated from interstitial zinc $\mathrm{Zn}_{i}$ and oxygen defects $[46,47]$. The band situated at $2.34 \mathrm{eV}$ can be assigned to intrinsic defects (oxygen vacancies, zinc interstitials, O interstitials, or anti-site defects) [48]. These emission bands are possible because they arise from levels of different energies created in the forbidden band. The position of the bands changes slightly with the concentration of the Ag doping (Figs. 9 and 10) and the $\mathrm{ZnO}$ thin film doped with 3 wt\% Ag displays the most intense luminescence bands.

\section{Conclusion}

Undoped and Ag-doped $\mathrm{ZnO}$ thin films were synthesized by sol-gel method and deposited onto glass substrate by dip-coating technique. Their structural, morphological and optical properties have been studied. The $\mathrm{X}$-ray diffraction showed that the thin films are polycrystalline and crystallized in hexagonal (wurtzite) structure with a preferential orientation of crystallites along $c$ axis. The crystallites have nanometric sizes. This result has been confirmed by the Raman, the SEM and the AFM investigations. The optical characterization has demonstrated that the prepared $\mathrm{ZnO}$ and $\mathrm{Ag}$-doped $\mathrm{ZnO}$ thin films are highly transparent in the visible domain. The energy of the optical band gap decreases from 3.30 to $3.26 \mathrm{eV}$ when $\mathrm{Ag}$ doping increases, and the photoluminescence spectra of films show an emission band in the ultraviolet $(380 \mathrm{~nm})$ and four bands in the visible region. The $\mathrm{ZnO}$ thin film with $3 \mathrm{wt} \% \mathrm{Ag}$ doping gave the most intense luminescence bands.

\section{References}

[1] R. Könenkamp, R.C. Word, M. Godinez, Nano Lett. 5, 2005 (2005).

[2] L.C. Claude, T.Z. Ramon, M.A. Ryan, Adv. Mater. 17, $1512(2005)$ 
[3] B. Mereu, O. Caglar, J.S. Cashmore, P.A. Losio, A. Salabas, I. Sinicco, Sol. Energy Mater. Sol. Cells 152, 147 (2016).

[4] H.J. Lim, D. Yong, Y.J. Oha, Sens. Actuat. A $\mathbf{1 2 5}$, 405 (2006).

[5] M. Miki-Yoshida, V. Collins-Martínez, P. AmezagaMadrid, P.A. Aguilar-Elguezabal, Thin Solid Films 419, 60 (2002).

[6] S.M. Hosseini, I.A. Sarsari, P. Kameli, H. Salamati, J. Alloys Comp. 640, 408 (2015).

[7] R. Kumar, D. Rana, A. Umar, P. Sharma, S. Chauhan, M.S. Chauhan, Talanta 137, 204 (2015).

[8] O. Bechambi, M. Chalbi, W. Najjar, S. Sayadi, Appl. Surf. Sci. 347, 414 (2015).

[9] A. Baltakesmez, S. Tekmen, S. Tuzemen, J. Appl. Phys. 110, 054502-7 (2011).

[10] S. Fay, U. Kroll, C. Bucher, E. Vallat-Sauvain, A. Shah, Sol. Energy Mater. Sol. Cells 86, 385 (2005).

[11] M. Harati, D. Love, W.M. Lau, Z. Ding, Mater. Lett. 89, 339 (2012).

[12] H. Belkhalfa, H. Ayed, A. Hafdallahd, M.S. Aida, R.T. Ighil, Optik 127, 2336 (2016).

[13] A. Gahtar, A. Rahal, B. Benhaoua, S. Benramache, Optik 125, 3674 (2014).

[14] M. Tomakin, Superlatt. Microstruct. 51, 372 (2012).

[15] T. Jannane, M. Manoua, A. Liba, N. Fazouan, A. El Hichou, A. Almaggoussi, A. Outzourhit, M. Chaik, J. Mater. Environ. Sci. 8, 160 (2017).

[16] F. Xian, K. Miao, X. Bai, Y. Ji, F. Chen, X. Li, Optik 124, 4876 (2013).

[17] F. Khan, S.-H. Baek, J.H. Kim, J. Alloys Comp. 584, 190 (2014).

[18] K. Necib, T. Touam, A. Chelouche, L. Ouarez, D. Djouadi, B. Boudine, J. Alloys Comp. 735, 2236 (2018).

[19] X. Du, J. Li, X. Bi, J. Alloys Comp. 698, 128 (2017).

[20] C. Lung, M. Toma, M. Pop, D. Marconi, A. Pop, J. Alloys Comp. 725, 1238 (2017).

[21] N. Srinatha, Y.S. No, V.B. Kamble, S. Chakravarty, N. Suriyamurthy, B. Angadi, A.M. Umarji, W.K. Choi, RSC Adv. 6, 9779 (2016).

[22] E. Fortunato, D. Ginley, H. Hosono, D.C. Paine, MRS Bull. 32, 242 (2007).

[23] Joint Committee for Powder Diffraction Standards, Power Diffraction File for Inorganic Materials, JCPDS 1979, p. 79

[24] A. Arunachalam, S. Dhanapandian, M. Rajasekaran, J. Anal. Appl. Pyrol. 123, 107 (2017).

[25] M. Dehimi, T. Touam, A. Chelouche, F. Boudjouan D. Djouadi, J. Solard, A. Fischer, A. Boudrioua, A. Doghmane, Adv. Condens. Matter Phys. 2015, 740208 (2015).

[26] R. Jayakrishnan, K. Mohanachandran, R. Sreekumer, C.S. Kartha, K.P. Vijayakumar, Mater. Sci. Semicond. Process. 16, 326 (2013).
[27] Y. Liu, J. Lian, Appl. Surf. Sci. 253, 3727 (2007).

[28] L. Castañeda, A. Maldonado, A. Escobedo-Morales, M. Avendano-Aleso, H. Gómez, J. Vega-Pérez, M.L. Olvera, Mater. Sci. Semicond. Process. 14 114 (2011).

[29] B. Rahal, B. Boudine, A.R. Khantoul, M. Sebais, O. Halimi, Optik 127, 6943 (2016).

[30] H. Benelmadjat, N. Touka, B. Harieche, B. Boudine, O. Halimi, M. Sebais, Opt. Mater. 32, 764 (2010).

[31] H. Benelmadjat, S. Boudjaadar, B. Boudine, A. Chelouche, O. Halimi, A. Boudrioua, J. Optoelectron. Adv. Mater. 13, 122 (2011).

[32] A.H. Shah, E. Manikandan, M.B. Ahmed, V. Ganesan, J. Nanomed. Nanotechol. 4, 168 (2013).

[33] A. Khan, J. Pak. Mater. Soc. 4, 5 (2010).

[34] L.N. Wang, L.Z. Hu, H.Q. Zhang, Y. Qiu, Y. Lang, G.Q. Liu, J.Y. Ji, J.X. Ma, Z.W. Zhao, Mater. Sci. Semicond. Process. 14, 274 (2011).

[35] W.J. Li, C.Y. Kong, H.B. Ruan, G.P. Qin, G.J. Huang, T.Y. Yang, W.W. Liang, Y.H. Zhao, X.D. Meng, P. Yu, Y.T. Cui, L. Fang, Solid State Commun. 152, 147 (2012).

[36] B. Hadžić, N. Romčević, D. Sibera, U. Narkiewicz, I. Kuryliszyn-Kudelska, W. Dobrowolski, M. Romčević, J. Phys. Chem. Solids 91, 80 (2016).

[37] Q.T.H. Ta, S. Park, J.S. Noh, J. Coll. Interface Sci. 505, 437 (2017)

[38] E. Mosquera, C. Rojas-Michea, M. Morel, F. Gracia, V. Fuenzalida, R.A. Zárate, Appl. Surf. Sci. 347, 561 (2015).

[39] C. Zegadi, K. Abdelkebir, D. Chaumont, M. Adnane, S. Hamzaoui, Adv. Mater. Phys. Chem. 4, 93 (2014).

[40] F. Xian, K. Miao, X. Bai, Y. Ji, F. Chen, X. Li, Optik 124, 4876 (2013).

[41] D. Basak, G. Amin, B. Mallik, G.K. Paul, S.K. Sen, J. Cryst. Growth 256, 73 (2003).

[42] S.J. Pearton, D.P. Norton, K. Ip, Y.W. Heo, T. Steiner, J. Vac. Sci. Technol. B 22, 932 (2004).

[43] A. Chelouche, D. Djouadi, H. Merzouk, A. Aksas, Appl. Phys. A 115, 613 (2014).

[44] P. Li, S. Wang, J. Li, Y. Wei, J. Lumin. 132, 220 (2012).

[45] X.R. Deng, H. Deng, M. Wei, J.J. Chen, J. Mater. Sci. Mater. Electron. 23, 413 (2012).

[46] K. Rokesh, A. Pandikumar, K. Jothivenkatachalam, Mater. Focus 3, 345 (2014).

[47] K. Rokesh, S.C. Mohan, S. Karuppuchamy, K. Jothivenkatachalam, J. Environm. Chem. Eng. 6, 3610 (2017).

[48] K. Xianwen, S. Fukai, S.P. Young, W. Yunjin, W.K. Tae, F. Dejun, Surf. Coat. Technol. 201, 6797 (2007). 